\title{
The Determinant of Organizational Performance of Moroccan Banks: Bank Opera Model Adapted to Moroccan Case
}

\author{
Youssef Alami \\ National School of Trade and Management of Tangier, Morocco \\ E-mail: Alamiyou@yahoo.fr \\ Fatima-Azzahra Elfhal \\ National School of Trade and Management of Tangier, Morocco \\ E-mail: Fatimaazzahra.elfhal@gmail.com
}

Received: January 10, 2019 Accepted: January 25, 2019 Published: March 13, 2019

doi:10.5296/ber.v9i1.14204 URL: https://doi.org/10.5296/ber.v9i1.14204

\begin{abstract}
This study aims to identify the determinants of organizational performance relevant of the Moroccan banks. To achieve this, an approach based on a BANK-OPERA model, which is inspired by the OPERA model, was chosen to be applied in the Moroccan environment. The empirical results of this research show that the model is validated in our context. However, some determinants, that have been considered crucial in the performance assessment using the tested model, are not decisive for the Moroccan banks 'performance.
\end{abstract}

Keywords: Organizational performance, Banks, Multiple correspondence analysis, Internal variables

\section{Introduction}

In the trade policy literature, there are two main streams of research on the determinants of business performance. The first represents the traditional economic thinking, which emphasizes the importance of external market factors in determining the success of a business. The second is based on the behavioural and sociological paradigm and sees the organizational factors and their adequacy within the environment as the main determinants of success. In this school of thought, little direct attention is given to the competitive position of the company; likewise, the economy has traditionally ignored the internal business factors. 


\section{Ml Macrothink}

Business and Economic Research

ISSN 2162-4860

2019, Vol. 9, No. 1

The theory or empirical evidence of linkages to performance abounds within each paradigm, but surprisingly little has been done to identify the organizational determinants of business, based on these internal factors. Similarly, very little work has been done to identify these determinants within banks, as a multi-product (or multiservice) enterprise, operating in an uncertain and volatile environment (Naylor, 1995, p: 58).

In this article, we will examine the internal factors affecting the organizational performance of the banking institutions, thus relying on the case of various Moroccan banks, as they were identified by the Bank-al-Maghreb Circular n ${ }^{\circ}$ 26. / G / 2006.

Using a single database, we will build and test a Bank-Opera model for organizational performance (Ömür Süer, 2003) on our panel, while highlighting only the internal dimensions of the model.

The problem of selecting a representative model seems particularly present in relation to the organizational dimension of the performance. This is due to the extent of the notion, the lack of studies in this field and therefore the theoretical basis, which limits the choice of models to be tested. The selected model, being little studied and never tested in the Moroccan context, seems adaptable to our study.

In the next two sections, we will present the used model adapting it to the Moroccan context. Furthermore, we will describe our data, explain the results and, in conclusion, we will discuss the implications of our results.

\section{The Bank-opera Model: An Empirical Evidence}

The BANK-OPERA model proposes to relate five categories of dimensions (Ömür Süer, 2003).These dimensions represent: banking environment, personality, activities, organization/ resources, potential/ results. Within these dimensions exist different variables, both internal (organizational) and external. In this case, we are interested to identify the four organizational variables, which are relevant for the Moroccan case.

\subsection{Identifying the Different Dimensions of the Model}

Our approach to the model of Ömür Süer (2003) is based to its adaptation to the Moroccan case.

\subsubsection{Personality Dimension}

The concept of personality is closely related to the notion of degree of capitalization (Demirgüç-Kunt and Huizinga, 1999), particularly, the distribution of capital, power and, consequently, of decision-making.

It is therefore appropriate to make two breakdowns, namely public/ private and local/ foreign banks.

The first aspect allows us to appreciate the contribution to risk bearing projects an /or sectors or those, which bear none or little profit, but are necessary for the country's economy. The local/ foreign distinction relates to the gap between the domestic banks as institutions 
belonging to a developing country (in our case) and foreign financial institutions (mostly French or other European).This distinction is very important as the European financial systems are more stable than the Moroccan financial system.

Based on the Bank-Al-Maghreb's reports, which identify the financial banking institutions, as well as the ownership of their capital, we were able to establish the following personality's categories of banks, operating in Morocco.

-Moroccan public banking institutions

-Moroccan private banking institutions

-Moroccan semi-public banking institutions

-Foreign financial institutions (mainly Western and French).

\subsubsection{Activity dimension}

The financial literature uses two criteria (C.Noyer, 1990) to define the activities of the banking institutions, in particular, the way in which resources are collected and the type of activity.

Depending on the resource collection mode, we distinguish between banks with branch network and banks without branches that turn to the capital markets to raise resources. According to Coussergues (1996), this is a crucial element since it controls the bank's clientele; its products, financial structure and organization. We distinguish between:

-Banking institutions with a large branch network

-Banks with an average branch network

-Banking institutions with a limited branch network

-Banks without a branch network.

We distinguish between different categories by searching for quartiles.

Referring to the type of activity of the bank, it differs according to whether the bank operates locally (onshore) or internationally (offshore) or it is a foreign bank which operates in the domestic market. It is customary to distinguish between domestic and foreign banks according to their location and not that of the parent company. As a result, a subsidiary of a French banking group based in Morocco is a Moroccan bank.

We will not maintain this tradition, which results in bringing under the same category all banks registered in Morocco. Instead, we will retain the distinction between local and foreign banks as it was initially determined by Demirgüç-Kunt and Huizinga (1997). Indeed, they have examined this point and have highlighted the disparities that may exist between the domestic and foreign banks, especially in terms of the global intermediation margin.

Moreover, in relation to the onshore/ offshore operation, De Coussergues (1996) distinguished them according to the existence or not of subsidiaries abroad. We can say that a 
bank is international if it has «agencies and subsidiaries abroad and/ or if the bank operations vis-à-vis non-residents exceed one third of the balance sheet total ".

Thus, this degree of internationalization defines the type of activity of the banking institution. We will distinguish between the following three types of institutions:

-Local Moroccan banking institutions: the bank is Moroccan and operates only in the domestic market

-Internationalized Moroccan banks: the bank is Moroccan but has subsidiaries abroad

-Foreign banking institutions, which operate in Morocco.

\subsubsection{Resources/ Organizations Dimension}

This dimension focuses on two key notions in any organization, namely material capital and human capital.

Regarding the human resources qualifications, we will define the different categories, according to the percentage of employees with university degree, which determines the staff capacity and subsequent the competitive advantage, which is not least important (De Coussergues, 1996).When compared to the total number of employees, this percentage is enabling us to identify 3 categories, namely:

-Banks with a high percentage of qualified employees

-Banks with an average percentage of qualified employees

-Banks with a low percentage of qualified employees.

Concerning the specialization of capital, it depends both on the level of guarantee offered by the banking institution and the allocation of resources collected by the bank. In order to appreciate this aspect, we will focus on the percentage of own funds. To do this, we will opt for the solvency ratio as a determinant of this dimension.

In the context of prudential regulation and in accordance with Bank-Al-Maghreb Circular No 26 / G / 2006, the solvency ratio is the ratio of overall prudential capital to risk-weighted amounts credit, market and operational risk. This ratio is calculated by most banking institutions in accordance to Basel 3 regulations that generally comply with the new minimum ratio, which came into force on 1 July 2015. In terms of ratio, we will classify the banks according to whether it is within the limits determined by the regulations, or it exceeds the limit by less than one point, or it exceeds the limit by more than one point, as follows:

-Banks with a ratio above the regulatory limit of more than one point

-Banks with a ratio above the regulatory limit of less than one point

-Banks with a ratio at or below the regulatory limit.

\subsubsection{Potential / Result Dimension}

We will respect the distinction made by Ömür Süer (2003) and will use as market 
determinants the market share in terms of assets in $\mathrm{n}-1$ and the past and present profitability of the assets. In his choice, Ömür Süer (2003) relies on the distinction using the OPERA model, initially made by Capet, Causse and Meunier (1983) between past (potential) and present results.

Thus, we distinguish between three categories of potential, represented by the market share in terms of assets in t-1 (in 2014):

-A high market share in terms of banks' assets.

-An average market share in terms of banks' assets.

-Low market share in terms of banks 'assets.

Concerning the profitability of banks assets, in this same line of analysis, we will distinguish between:

-Very high return on assets

-Moderate return on assets

-Average return on assets

-Moderately low return on assets.

We will use this criterion and differentiation referring to2014 as past profitability and to 2015 as present profitability.

3. The Bank-Opera Model: Its Application to the Moroccan Banking Institutions

\subsection{Statistical Principles and Methods}

Our study is based on a sample of Moroccan private and public banks as well as Western and Eastern commercial banks established in Morocco. According to the annual supervision report published by Bank-Al-Maghreb for the 2015 financial year, nine Moroccan banks hold a monopoly leaving a percentage of only around $1 \%$ of market share for the other banks. We will thus be content to shed light on the behemoths of the Moroccan banking sector.

The applied model is be based on the BANK-OPERA model, which is inspired by the OPERA model (Capet, Causse et Meunier, 1986), using multiple correspondence analysis (MCA).We chose this method due to variables' nature (qualitative). The MCA allows the analysis of several qualitative variables (the dimensions of the model) as well as the cartographic visualization of the proximities between the qualitative variables and the observations.

This study aims to shed light on the existing relationships between the dimensions of the model. It includes 32 studied categories and 9 observations.

\subsection{Research Results}

The Multiple Correspondence Analysis (MCA) applied to the sample described above clearly indicates that the object dimensions of the study explain $73.80 \%$ of the variance. The table 
below summarizes the data shown in the table in the Appendix

Table 1. Inertia percentages per dimension

\begin{tabular}{|l|l|l|l|}
\hline \multicolumn{4}{|c|}{ Principal Cumulative } \\
\hline Dimension & inertia & percent & percent \\
\hline $\operatorname{dim} 1$ & .5057107 & 68.52 & 68.52 \\
\hline $\operatorname{dim} 2$ & .1429175 & 19.36 & 87.88 \\
\hline $\operatorname{dim} 3$ & .0200982 & 2.72 & 90.60 \\
\hline $\operatorname{dim} 4$ & .0003192 & 0.04 & 90.64 \\
\hline Total & .7380952 & 100.00 & \\
\hline
\end{tabular}

The total inertia of the clouds depends on the number of variables introduced into the analysis.

The analysis summarized in the table indicates that the first three dimensions explain 90.60\% of the studied phenomenon, which is an admitted score. The coordinates of the categories on the various axis are shown in the table included in the Appendix. From this table we can explain the 3 dimensions.

The first dimension can be explained by the following variables:

\begin{tabular}{|l|l|}
\hline \multicolumn{1}{|c|}{ Positive } & \multicolumn{1}{c|}{ Negative } \\
\hline Moroccan public banking institutions, & Average return on assets, \\
Western banking institutions, & Average branch network, \\
Local Moroccan banking institutions & Average market share, \\
Western banking institutions, & Percentage of employees with a high level \\
Low market share, & university degree, \\
Percentage of employees with a basic level & Percentage of employees with an average \\
university degree, & level university degree, \\
High solvency rate, & High market share, \\
Large branch network, & Limited branch network, \\
High return on assets. & Moroccan banks internationalized, \\
& Average return on assets, \\
& Low solvency rate. \\
\hline
\end{tabular}

These Cond dimension is explained by the following variables:

\begin{tabular}{|l|l|}
\hline \multicolumn{1}{|c|}{ Positive } & \multicolumn{1}{c|}{ Negative } \\
\hline Moroccan public banking institutions, & Limited branch network, \\
Percentage of employees with a basic level & Foreign banking institutions, \\
university degree, & Low return on assets, \\
Average solvency rate, & Limited branch network, \\
Average profitability of assets, & Moroccan banks internationalized, \\
Local Moroccan banking institutions, & Average market share, \\
Large branch network, & Low return on assets. \\
Average return on assets. & \\
\hline
\end{tabular}


The third dimension can be explained by the following variables:

\begin{tabular}{|c|c|}
\hline Positive & Negative \\
\hline $\begin{array}{l}\text { Moroccan public commercial banking } \\
\text { institutions, } \\
\text { Moroccan private commercial banking } \\
\text { institutions, } \\
\text { Local banking institutions, } \\
\text { Internationalized banking institutions, } \\
\text { Average percentage of employees with an } \\
\text { university degree, } \\
\text { Low market share, } \\
\text { Average return on assets, } \\
\text { Average solvency rate, } \\
\text { Limited branch network. }\end{array}$ & $\begin{array}{l}\text { Large branch network, } \\
\text { Foreign commercial banks, } \\
\text { Foreign banking institutions, } \\
\text { Average return on assets, } \\
\text { Average branch network, } \\
\text { Average market share, } \\
\text { High market share, } \\
\text { High solvency rate, } \\
\text { Low solvency rate. }\end{array}$ \\
\hline
\end{tabular}

The diagram in the Appendix represents the crossing between the first two dimensions.

The mentioned diagram highlights some elements which we will confirm further along the study.

The personality dimension reveals that the Moroccan private banks remain the most successful ones. There is a number of factors that favours their high performance, including qualified staff, high market share, very high ROA (return on assets), large branch network, average solvency rate and high solvency rate. We find that the public banks as well as the semi-public banks are less efficient, although they have a large branch network and showed high Return on Assets in 2015 and average one in 2016.These categories of banks retain an average or even low market share as well as an average solvency rate. Concerning the foreign banks, although they retain a high market share and a high level of staff qualification, they are not the best performers. The result of the other parameters remains mixed. Therefore, the personality dimension, which is manifested by the public/ private aspect, is crucial in determining the organizational performance of the banking institutions in Morocco.

Regarding the activity dimension, characterized by the branch network and degree of internationalization, we note that local banks don't run higher risks of lower efficiency than the internationalized banks. In fact, the local banks tend to have an average branch network but still a medium to high return on assets. The internationalized banks, on the other hand, have a large branch network and a very high return on assets. We conclude that the activity dimension is not essential in determining the performance of the banking institutions in Morocco.

Regarding the organization/ resources dimension, which focuses on human and material capital, we note that there is an obvious relationship between the performance of a bank and the qualification of its staff. The best-performing and medium-performing companies have highly qualified staff. This allows them to provide high quality services to both local and foreign clients. Regarding the solvency rate, the most successful financial institutions, namely 
the Moroccan private banks have both a very high ROA and high solvency rate. Thus, there is a certain coherence between the two values. We can agree that the solvency rate is preeminent in determining the performance of the banking institutions in Morocco.

Regarding the potential/ result dimension, which focuses on the bank's market share in terms of assets and the financial profitability of the latter, we recognize that the market share is crucial in determining the banking institutions' performance in Morocco. Indeed, the universality of the bank as well as its durability requires a significant market share. This dimension allows the bank to ensure certain stability, satisfactory financial ratios and a positive impact on the Moroccan economy. This aspect is the driving force behind the banks merger as a measure to prevent bankruptcy.

To support the results of this study, particularly the non-significance of the activity dimension, which is characterized by the branch network size and the degree of internationalization, as well as their conformity to the Moroccan economic landscape, the identified elements will be subjected to analysis, using a structured maintenance questionnaire included in the Annexure together with guidelines. Indeed, if all remaining elements were equal, the impact of the branch network of the Moroccan banks does not represent major disparities. We will test witch variable is more significant: the branch network or the agencies network.

\subsection{The Interview Guide: Validation or Rejection of Non-significant Elements of the Research}

The annexed questionnaire, directed to CEO's of Moroccan banks located abroad (Côte d'Ivoire, Gabon, and Mali) as well as to experts in banking and bank management strategies, highlights opposed results. The notion of "branch agencies" takes over the concept of "branch network". This is explained by a quasi-equitability between the branch networks of various Moroccan banks. Concerning the internationalization aspect, it is of major importance contrary to the previous results. The analysis highlights an aspect, which is not included in the used model, however, it is specific to the Moroccan landscape, namely the country's historical heritage (protectorate) and the specialization of some banks in specific areas such as agriculture. It would then be appropriate to consider these two notions in later studies.

\section{Conclusion}

The objective of this study is to identify the organizational determinants of the performance of the banking institutions in Morocco. To achieve this end, an approach based on a BANK-OPERA model, which is inspired by the OPERA model, was chosen to be tested in the Moroccan environment. The empirical results of this research show that the dimensions of the model are not all validated in our context. We rejected some determinants, which although deemed necessary for the banking institutions performance according to the tested model, are not decisive for the performance of the Moroccan banks.

In conclusion, the study shows that the personality dimension, manifested by the public/ private aspect is crucial in determining the organizational performance, while the activity dimension is not critical in determining the performance of the banking institutions in Morocco. 


\section{Macrothink}

Business and Economic Research

ISSN 2162-4860

2019, Vol. 9, No. 1

Regarding the organization/ resources dimension, which focuses on human and material capital, we can agree that the solvency rate is preeminent in determining the performance of the banking institutions in Morocco. However, the staff qualification is important without being essential.

Concerning the potential/ result dimension, which is expressed by the bank's market share in terms of assets as well as financial profitability, we realize that the market share is fundamental in determining the performance of the banks in Morocco.

Notwithstanding, it should be noted that our results are limited. The used model does not allow generalization and delimitation of the different determinants. Also, a multitude of determinants and organizational aspects (including the notion of centralization/ decentralization) that broaden the study field, calls for testing other models of organizational determinants, which rely on other statistical methods and incorporate more variables. The confrontation of various models will, without doubt, contribute to an in-depth understanding of the different organizational determinants and will allow us to determine which ones are relevant for the Moroccan case. As far as we know, there are not many recent developments in this type of research, particularly in Morocco.

\section{References}

Capet, Causse et Meunier (1986). Diagnostic, Organisation, Planification d'Entreprise, $\left(2^{\text {nd }}\right.$ Ed), Economica.

Demirgüç-Kunt, A., \& Huizinga, H. (1999). Determinants of commercial bank interest margins and profitability: some international evidence. World Bank Economic Review, 14(2), 379-408. https://doi.org/10.1093/wber/13.2.379

De Coussergues, S. (1996). Gestion de la Banque (2 ${ }^{\text {nd }}$ Ed), Paris, Dunod

Kotler, P., \& Bernard, D. (1997). Marketing Management, ( ${ }^{\text {th }}$ Ed), Paris, Publi-Union Editions.

Naylor, J. A. (1995). The Essentials of Money and Banking I, Research and Education Association, New Jersey

Ömür, S. (2003). Les Déterminants Organisationnels de la Performance des Banques en Turquie, 24th Congres of french Association of Accounting. 


\section{Appendix}

Appendix 1. Table: Main coordinates of the model

\begin{tabular}{|c|c|c|c|c|c|c|c|c|c|c|c|c|}
\hline \multirow[b]{2}{*}{ Categories } & \multicolumn{3}{|c|}{ overall } & \multicolumn{3}{|c|}{ dimension_1 } & \multicolumn{3}{|c|}{ dimension_2 } & \multicolumn{3}{|c|}{ dimension 3} \\
\hline & mass & quality & \%inert & coord & sqcorr & contrib & coord & sqcorr & contrib & coord & sqcorr & contrib \\
\hline \multicolumn{13}{|l|}{ PERSONNALITE } \\
\hline PERS1 & 0.042 & 0.883 & 0.047 & 0.765 & 0.283 & 0.024 & 1.599 & 0.544 & 0.107 & 0.727 & 0.056 & 0.022 \\
\hline PERS2 & 0.042 & 0.934 & 0.065 & -1.601 & 0.892 & 0.107 & -0.362 & 0.020 & 0.005 & 0.525 & 0.021 & 0.011 \\
\hline PERS3 & 0.042 & 0.875 & 0.044 & 0.836 & 0.356 & 0.029 & -1.237 & 0.343 & 0.064 & -1.253 & 0.176 & 0.065 \\
\hline \multicolumn{13}{|l|}{ ACTIVITE } \\
\hline Act1 & 0.042 & 0.883 & 0.047 & 0.765 & 0.283 & 0.024 & 1.599 & 0.544 & 0.107 & 0.727 & 0.056 & 0.022 \\
\hline Act2 & 0.042 & 0.934 & 0.065 & -1.601 & 0.892 & 0.107 & -0.362 & 0.020 & 0.005 & 0.525 & 0.021 & 0.011 \\
\hline Act3 & 0.042 & 0.875 & 0.044 & 0.836 & 0.356 & 0.029 & -1.237 & 0.343 & 0.064 & -1.253 & 0.176 & 0.065 \\
\hline \multicolumn{13}{|l|}{ RESSOURCES } \\
\hline ressources 1 & 0.056 & 0.924 & 0.044 & -1.117 & 0.858 & 0.069 & 0.287 & 0.025 & 0.005 & 0.524 & 0.041 & 0.015 \\
\hline ressources 2 & 0.042 & 0.842 & 0.029 & 0.564 & 0.246 & 0.013 & 0.253 & 0.022 & 0.003 & -1.835 & 0.574 & 0.140 \\
\hline ressources 3 & 0.028 & 0.896 & 0.050 & 1.389 & 0.582 & 0.054 & -0.954 & 0.121 & 0.025 & 1.704 & 0.193 & 0.081 \\
\hline \multicolumn{13}{|l|}{ DIPLOME } \\
\hline DIP 1 & 0.069 & 0.912 & 0.033 & -0.780 & 0.684 & 0.042 & -0.397 & 0.078 & 0.011 & -0.779 & 0.150 & 0.042 \\
\hline DIP 2 & 0.042 & 0.914 & 0.042 & 1.188 & 0.762 & 0.059 & -0.083 & 0.002 & 0.000 & 1.125 & 0.150 & 0.053 \\
\hline DIP 3 & 0.014 & 0.813 & 0.022 & 0.336 & 0.039 & 0.002 & 2.236 & 0.754 & 0.069 & 0.522 & 0.020 & 0.004 \\
\hline \multicolumn{13}{|l|}{ FOND_PROPRE } \\
\hline FP1 & 0.042 & 0.932 & 0.020 & 0.169 & 0.032 & 0.001 & -1.345 & 0.900 & 0.075 & -0.030 & 0.000 & 0.000 \\
\hline FP2 & 0.069 & 0.889 & 0.021 & -0.178 & 0.056 & 0.002 & 0.913 & 0.648 & 0.058 & 0.690 & 0.185 & 0.033 \\
\hline EP3 & 0.014 & 0.805 & 0.026 & 0.381 & 0.043 & 0.002 & -0.527 & 0.036 & 0.004 & -3.359 & 0.727 & 0.157 \\
\hline \multicolumn{13}{|l|}{ PART_MARCHE } \\
\hline PM1 & 0.042 & 0.930 & 0.030 & -0.974 & 0.711 & 0.039 & -0.559 & 0.103 & 0.013 & -0.838 & 0.116 & 0.029 \\
\hline PM2 & 0.056 & 0.818 & 0.013 & 0.036 & 0.003 & 0.000 & 0.896 & 0.791 & 0.045 & -0.224 & 0.025 & 0.003 \\
\hline PM3 & 0.028 & 0.896 & 0.050 & 1.389 & 0.582 & 0.054 & -0.954 & 0.121 & 0.025 & 1.704 & 0.193 & 0.081 \\
\hline \multicolumn{13}{|l|}{ ROA 15} \\
\hline $\mathrm{ROA}(\mathrm{TE})$ & 0.042 & 0.934 & 0.065 & -1.601 & 0.892 & 0.107 & -0.362 & 0.020 & 0.005 & 0.525 & 0.021 & 0.011 \\
\hline $\mathrm{ROA}(\mathrm{ME})$ & 0.069 & 0.894 & 0.033 & 0.640 & 0.474 & 0.028 & 0.780 & 0.310 & 0.042 & -0.658 & 0.110 & 0.030 \\
\hline $\mathrm{ROA}(\mathbb{M})$ & 0.014 & 0.888 & 0.057 & 1.603 & 0.341 & 0.036 & -2.813 & 0.462 & 0.110 & 1.714 & 0.086 & 0.041 \\
\hline \multicolumn{13}{|l|}{ ROA_ 16} \\
\hline $\mathrm{ROA}(\mathrm{TE})$ & 0.042 & 0.934 & 0.065 & -1.601 & 0.892 & 0.107 & -0.362 & 0.020 & 0.005 & 0.525 & 0.021 & 0.011 \\
\hline $\mathrm{ROA}(\mathrm{ME})$ & 0.069 & 0.894 & 0.033 & 0.640 & 0.474 & 0.028 & 0.780 & 0.310 & 0.042 & -0.658 & 0.110 & 0.030 \\
\hline $\mathrm{ROA}(\mathrm{M})$ & 0.014 & 0.888 & 0.057 & 1.603 & 0.341 & 0.036 & -2.813 & 0.462 & 0.110 & 1.714 & 0.086 & 0.041 \\
\hline
\end{tabular}




\section{Macrothink}

Business and Economic Research ISSN 2162-4860 2019, Vol. 9, No. 1

Appendix 2. Diagram: Symmetrical representation of the BANK-OPERA model dimensions adapted for Moroccan banks.

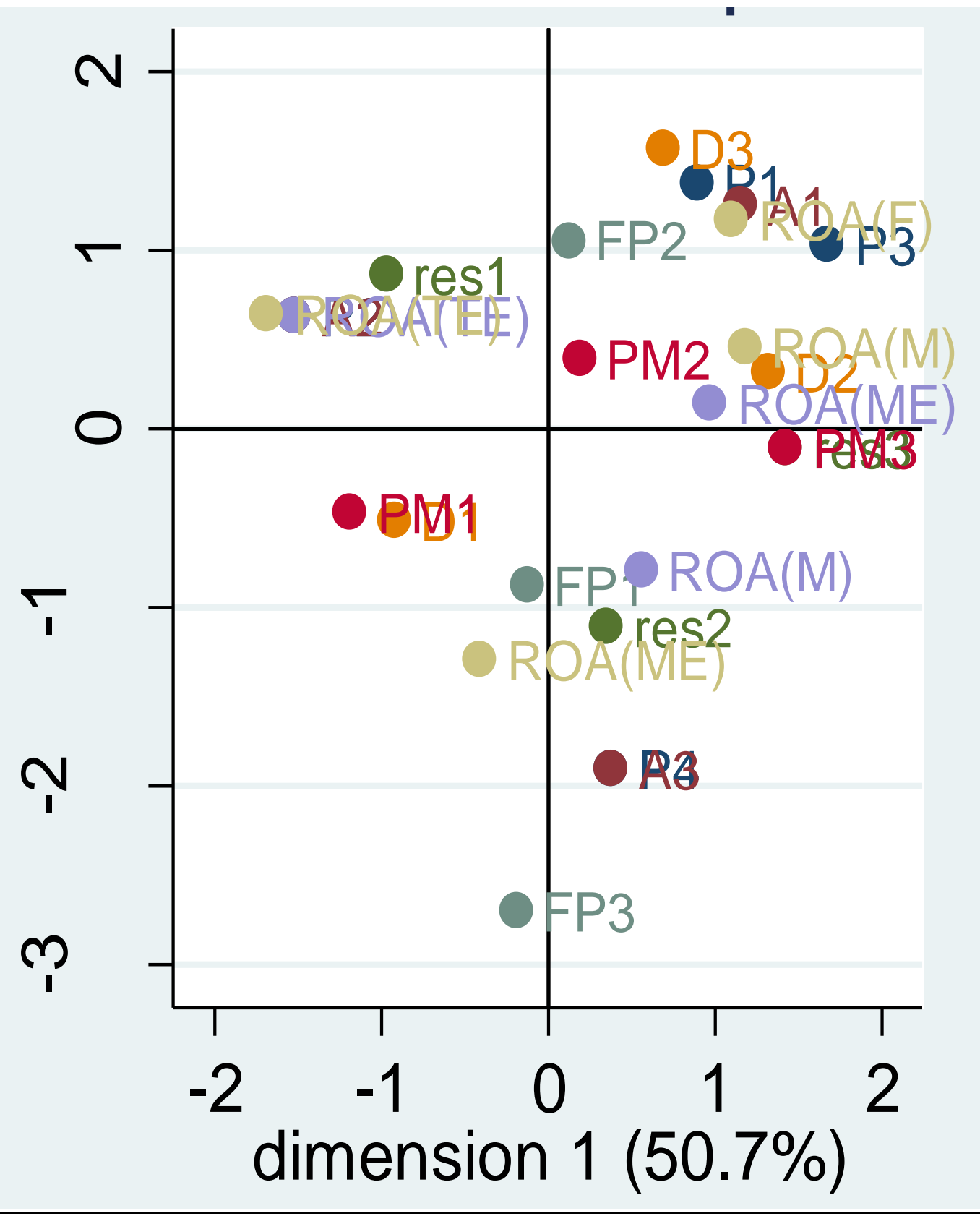

Appendix 3. Study questionnaire

Surname:

First name:

Business:

Position:

E-mail: 


\section{Macrothink}

Business and Economic Research

ISSN 2162-4860 2019, Vol. 9, No. 1

The purpose of this questionnaire is to validate or reject one of the dimensions of organizational performance, namely the activity dimension characterized by the branch network and the degree of internationalization.

1) Do you think that internationalization is one of the determinants of the performance of a banking institution?

Yes

No: Why?

2) Does your bank perceive the impact of the internationalization on the financial ratios as well as on the performance indicators as being significant? If yes, on which ones?

3) What tools do you use to evaluate this impact?

4) Do you think that the branch network impacts the performance of the banking institutions?

$\square$ Yes No: Why?

5) Do you think there is a significant difference between the branch networks of the banks in Morocco?

$\square$ Yes No: Why?

6) In your opinion, between these two elements, which one is more significant indicator in the evaluation of the performance of the banking institutions?

$\square$ The branch network

$\square$ The agencies network

Thank you for taking the time to participate in this study.

\section{Copyright Disclaimer}

Copyright for this article is retained by the author(s), with first publication rights granted to the journal.

This is an open-access article distributed under the terms and conditions of the Creative Commons Attribution license (http://creativecommons.org/licenses/by/3.0/). 